Article

\title{
Do Hierarchical Jumps in CEO Succession Invigorate Innovation? Evidence from Chinese Economy
}

\author{
Muddassar Sarfraz ${ }^{1}\left(\mathbb{D}\right.$, Wang Qun ${ }^{1,2}$, Syed Ghulam Meran Shah ${ }^{3, *}$ and Zeeshan Fareed ${ }^{4}$ \\ 1 Department of Management and HR, Business School, Hohai University, Nanjing 211100, China; \\ muddassar@hhu.edu.cn (M.S.); wqun@hhu.edu.cn (W.Q.) \\ 2 Provincial Collaborative Center of World Water Valley and Water Ecological Civilization, \\ Nanjing 211100, China \\ 3 School of Business Administration, Southwestern University of Finance and Economics, \\ Chengdu 61130, China \\ 4 School of Finance, Zhongnan University of Economics and Law, Wuhan 430073, China; \\ zeeshanfareed@hotmail.com \\ * Correspondence: ghulam_meeran2001@yahoo.co.in
}

Received: 19 February 2019; Accepted: 26 March 2019; Published: 4 April 2019

\begin{abstract}
The objective of this study is to analyze Chief executive officer (CEO) succession via hierarchical jumps in Chinese listed firms which orientate towards innovative activity. Good corporate governance is a vehicle to attain the competitive advantage which ultimately makes the organizational sustainability undeterred. The current study will test not only low hierarchical jumps but also medium hierarchical jumps in CEO succession. The study will identify the relationship between specific attributes like education, age and the duality of CEO successors via hierarchical jumps with innovation. We have analysed the data of Chinese listed firms on Shenzhen and Shanghai stock exchanges for the years 2012-2016. Significantly, it has been observed that CEO successors via hierarchical jumps orientate towards innovative activity amongst Chinese listed firms. Conclusively, empirical results have unveiled that hierarchical CEO succession escalates the firms' innovation. It has also been contemplated that not only the low hierarchical jumps but also medium hierarchical jumps in CEO succession invigorate the organizational innovation. Mature firms with a substantial return on assets or earning per share and having less loan burden concentrate on innovative activity decisively. It has been demonstrated that specific attributes like education, age and the duality of hierarchical CEO successors have no relationship with innovation. The study results are robust via confirmation of 2SLS instrumental regression.
\end{abstract}

Keywords: corporate governance; CEOs Succession; hierarchical jumps; innovation; sustainability; Chinese firms

\section{Introduction}

The prime objective of good corporate governance is to execute strategies [1] which can ensure minority shareholders rights and enhance investors' funds [2]. Innovation is the key to strengthen organizational sustainability. In this regard, Damanpour [3] enunciated that organizational innovation not only assists in confronting the dynamic environment of business but also maintains the sustainability of firms. Similarly, Aarstad [4] stated that innovation is the key element to sustain a competitive advantage. Therefore, it can be contemplated that innovation is the significant vehicle for maintaining sustainability which ultimately boosts the firms' growth.

More specifically, this study reveals the significance of the corporate mechanism (while analysing hierarchical CEO succession) for firms' innovation, which regularizes sustainability. Corporate governance, particularly the role of the Chief executive officer (CEO), is widely reviewed by academics and 
practitioners as a critical factor which influences firm performance. Firms with better corporate governance show higher performance persistence [5]. The traditional resource-based theory (RBV) enunciates that top management-level teams can assist firms in sustaining their competitive advantages [6], and the CEO plays a pivotal role in achieving the stated goals. The existing literature analyses the effect of either a CEO's characteristics or a CEO departure/succession on a firm's performance. A humble $\mathrm{CEO}$ and his/her top management team are found to be associated with stronger firm performance in the United States [7]. An empowered and independent board of directors in China enhance firm value and are associated with less earnings management [8]. A family CEO in China tends to disclose more information which leads to about $25 \%$ lower stock price synchronicity [9].

Being an emerging market, China is alluring investors by adopting an advanced corporate structure [10]. It has ameliorated its corporate governance mechanism [11]. However, government intervention is vigorous among the state-owned enterprises (as CEOs are not appointed while being selected [12]). Even, non-state-owned enterprises are partially controlled by the government (as their CEOs are politically linked). Wu [13] revealed that among non-SOEs, $40 \%$ of CEOs are politically connected because they can get an advantage from the government. In this regard, they will have to promote the government's agendas.

Consequently, CEOs are turned over forcefully for devastated firms' growth. The extant literature has demonstrated the same cause (poor performance) for forceful turn over [14,15]. CEO succession affects the performance asymmetrically, but scant research has been conducted while demonstrating the relation between CEO succession and organizational innovation. Manifestly, a voluminous literature has already evaluated the attributes of CEO influencing the innovation within the organization. In this regard, the prior literature has contemplated that, overconfidence, personal links, young age and alluring compensation packages of the incumbent CEO orientate him or her towards innovative adaptability [16-19]. However, it is not being able to evaluate the aftermath of CEO succession on innovation. The prior studies also indicate that innovation and corporate governance structure are interlinked. According to Crossan [20], organizational innovation is based on sound leadership following well-defined strategies to boost organizational profitability.

From the Chinese perspective, it has been observed that the intensity of innovation among public sectors is less as compared to the private sector [21]. On the contrary, because of the continuous transitioning in corporate structure reforms, public sector organizations are oriented to adopt innovative strategies [22]. The intervention of government is still vigorous despite bringing massive changes through reforms and plans for promoting innovation at the national level (Chinese launched 15 years plan to adopt innovation and become "innovation-oriented society" till 2020) [23]. The incumbent CEOs in SOEs (state-owned enterprises) are either ex-bureaucrats or government officials [12]. Even non-state owned firms are controlled via politically-linked incumbent CEOs [13]. In such a scenario, the corporate mechanism of Chinese organizations can never be impeccable. Despite the novel corporate structure, China is growing fast and has taken the drastic step of "imitation to innovation" [21]. Specifically, it would be interesting to contemplate how corporate governance mechanisms influence the two types (SOEs and non-SOEs) of firms' innovation. State-owned enterprises are under strict surveillance from the government via government ownership while non-State-owned enterprises are mostly family-owned firms seeking for profit only. China is a relational economy in which guanxi (relation) is highly significant. Hierarchical position among board members is considered as prestigious to enhance the relationships among higher authorities. Manifestly, scholars have enunciated the significance of hierarchy for the enhancement of efficiency within the organization [24]. The CEO is among the apex of the hierarchical ladder, which can be departed forcefully or frequently.

\section{Research Gap and Contribution}

Conclusively, prior literature has demonstrated the impact of CEO succession. Tien and Chen [25] observed that intensity of innovation remains undeterred while CEO succession occurs) on innovation. In this regard, Wong [26] demonstrated the positive relation between internal CEO succession and 
innovation, yet there is an acute need for contemplation of the impact of a CEO successor via hierarchical jumps in innovation. In a recent study, Shah [27] evaluated that hierarchical CEO successions are conducive for firms' performance but did not examine the relation between hierarchical CEO succession and innovation. This research paper has filled the research gap by evaluating the effectiveness of hierarchical CEO's succession on organizational innovation. Specifically, this study has contributed in three ways. Firstly, the formulation of hierarchical jumps by contemplating the total hierarchical rank of the board of directors (as the hierarchical rank among the Chinese organizations signifies the authority, which is allocated according to the seniority) [8]. Secondly, a hierarchical rank can be dissected into a high, middle and low level [28]. Therefore, the three types of hierarchical jumps have been formulated (high, middle and low level). Thirdly, this research also signifies the specific types of hierarchical jumps in CEO succession which invigorate the innovation.

\section{Theoretical Framework and Hypothesis Development}

\subsection{Corporate Governance in China}

Since its inception, China has adopted a socialist system allowing the central government to play a hegemonic role by its excessive control of every institution. With the strict intervention by the government in every institution, Chinese organizations have been adhering to these strict laws for the last three decades. Government officials were appointed to control such institutions. Due to government intervention, firms were strictly bound to follow the rules rather than to launch any innovative strategy for firms' growth. Due to this excessive surveillance by the Government, Chinese higher authority realized that the efficiency of corporate governance became devastated. Firstly, in 1990, the ownership structure in state-owned enterprises was ameliorated. Though a significant stakeholder was the government, partial control was transferred to the enterprises.

Moreover, the Chinese Securities Regulatory Commission (CSRC) was launched in 1992; the objective of the Chinese securities regulatory commission was to regulate the securities. Chinese securities regulatory commission promulgated well-defined rules for the listed companies (penalties in case of violating the rules and regulation) [12]. From 2003, it was imposed that listed companies must have a board of directors and a supervisory board [29], but the prodigious step was taken in 2007 when Chinese securities regulatory commission launched a 3-year plan to improve the corporate mechanism.

China ameliorated its financial system by converting non-tradable shares to tradable [30] and mitigated the threat of expropriation for minority shareholders [11]. Though China has adopted the advanced countries corporate governance system [10], it is still confronted with inefficiency due to weak corporate laws, even some corporate laws are still ambiguous. Accordingly, Yang [31] evaluated that weak corporate laws are the cause of agitating financial fraud among the Chinese listed companies. The role of CEOs in state-owned enterprises is questionable as they are appointed via government intervention and forcefully turned over in the case of poor performance [32]. Moreover, they are less compensated as compared to western countries [12], which is why they cannot perform diligently. So, the intensity of forceful turnover in state-owned enterprises is high as compared to non-state-owned enterprises [12]. CEO duality is also a common phenomenon among the Chinese organizations which can also devastate the firms' growth because of his/her dallying attitude while taking a decision [33]. Despite having a dual office, CEOs cannot save themselves from forceful turnover [34]. To encapsulate, despite a novel corporate mechanism, Chinese organizations are booming.

Meanwhile forceful turnover is an inevitable phenomenon among Chinese organization. Argumentatively, it would be constructive to analyse whether the incumbent CEOs via hierarchical jumps orientate towards innovation activity or not. Shah [27] unveiled that hierarchy in CEOs succession is a blessing in disguise for firms' growth. In this regard, this study further investigates the impact of hierarchical CEO succession on organizational innovation. 


\subsection{Corporate Governance and Innovation}

Organizational innovation is necessary for the long-term survival of organizations in the current dynamic environment of business. In emerging markets, there is still an acute requirement of innovation not only to ameliorate the infrastructure but also adopt innovative activity; these countries can boost their economy. Even among the newly launched entrepreneurial ventures, innovation plays the role of backbone to survive while confronting the competitive environment. It is also a way to have a competitive advantage over peers' organizations [35]. Some research has also indicated the positive impact of human resource management on organizational innovation. They emphasize internal collaboration and motivation, and commitment of employees is vital for organizational innovation [36]. Similarly, Zhang [37] showed the intensity of collaboration as a cataclysmic vehicle for boosting firms' innovation.

Some prior studies have evaluated the impact of CEOs on innovative activity representing how different aspects (internal structure of corporate governance) influence the innovative procedure. In this connection, Dong [38] evaluated that the outsider, independent directors encourage organizational innovation. Moreover, managers having shares within the organization compel him to intensify the organizational innovation. Keeping this view in the same vein, Mao [19] revealed that compensation packages also allure CEOs to orientate towards innovation. Galasso [16] that overconfident CEOs are over-optimistic and always take the risky decisions which ultimately orientate them to invest more in innovation.

Similarly, Hirshleifer [39] analyzed 1500 US firms while contemplating that overconfident CEOs not only enhance the stock return but also persuade the product innovation. Meanwhile, Faleye [17] evaluated that personal links also act as a vehicle for the enhancement of innovative activity within the organization. Through these connections, they can excel in the number of patents of their organizations.

Significantly, some study showed that CEOs with long tenure endorse innovative activity. Long tenure indicates the supremacy and authority of the CEO and this self-independence allows him to take audacious strategies for the enhancement of innovation [40]. The role of non-executive's members is also significant in boosting innovation. Additionally, the independence of directors is also considered to be extremely significant for the improvement of innovation (especially the increase in the count of citations for the patent) [41].

Substantially, the promulgation of specific laws has also promoted innovative activities among emerging countries. Specifically, after the confirmation of intellectual property rights, the intensity of innovation increased vigorously [42]. Similarly, in China, after launching IP rights, firms have been motivated to adopt innovative activities [43]. Moreover, with the permission of privatization of SOEs and strengthening of the IP rights, innovation has been enhanced vehemently. Meanwhile, with the implication of new rules (no tradable to tradable shares), innovation has been endorsed by the top management of Chinese SOEs decisively [43]. On the contrary, high government concentration among state-owned enterprises ((According to Chen [44]. the numbers of board members are different for every firm. So, board members are dissected (dividing by 3) into low, medium and high-rank intervals (see in Appendix A)) weakens the firms' innovative intensity [45] as compared to the firms having less government concentration.

There is scant literature which evaluates the impact of CEO succession on firms' innovative activity. However, Tien [25] revealed that CEO succession does not disturb the momentum of innovative activity within the organization. Conclusively, CEO compensation enforces them to launch innovative strategies undauntedly. Additionally, Wong [26] analyzed the Chinese-based family firms in Taiwan while contemplating that CEO successor has specific knowledge that boosts the innovation significantly. Evidently, Cummings [46] evaluated that the outsider CEO successors decline the research and development (R\&D) activity while suggesting that the firm should prefer an insider CEO who enhances research and development $(R \& D)$ investment seeking for long-term planning. In this regard, Carney [47] demonstrated the positive relation of the family firm's succession with the innovation output. Following the prior research, our empirical results contribute while evaluating that hierarchical 
CEO succession boosts the firm's innovation. Explicitly, medium and low hierarchical jumps escalate the firms' innovation.

\subsection{Hypothesis Development}

The procedure of CEO succession (either regular or irregular) among organizational history. The existing literature has conceded that poor performance is the cause of forceful turnover [15]. Relevantly, the circulation of power theory argues that owing to obsolete strategies, the firms' performance becomes devastated which leads the CEOs towards early departure. Due to internal contestation, agency loss is also deterred which can assist the CEOs in orientating towards organizational innovation.

Meanwhile, some study witnessed that hierarchy does boost the innovative process [48]. Additionally, Balsmeier [41] unveiled that among the hierarchical ladder, the role of independent directors is highly significant for boosting the innovation output.

Cummings and Carney [46,47] concluded the positive relation between CEO succession and innovation. In this connection, Cucculelli [49] observed that an external CEO successor enhances the innovation, but still, it is required to evaluate whether an internal CEO successor via hierarchical jump endorses innovative activity or not. Hierarchical jumps in CEOs succession escalate the firms' performance [27]. So, based on prior research, our first hypothesis is described as following.

H1: The incumbent $C E O$ via hierarchical jump enhances the innovation (input $\mathcal{E}$ output)

Impact of Successor Via Low or Medium Hierarchical Jump on Innovation

Few studies have been conducted on analyzing the impact of CEO succession on innovation. Some authors have demonstrated the impact of succession in family-owned firms on innovation, evaluating the positive relation [41], [50]. Similarly, scholars have revealed that insider CEOs are persuaded to enhance the R\&D investment which accelerates research and development $(R \& D)$ productivity.

Hayes [51] observed the relationship between the hierarchy of authority on the innovative process. They unveiled that hierarchy is necessary while selecting innovative ideas. Hierarchy acts like a two-edged sword as it enhances the management efficiency while it also disintegrates the board members according to their hierarchical rank. The extant literature has manifested that simple hierarchy consolidates the interaction among the board members [18] which also assists in promulgating the new strategies [52].

Most importantly, social psychologists have contemplated the behavioral reactions of an individual due to the distinct intensity of prestige linked with hierarchical position [53]. Moreover, the benefit of reward with high position also alludes to the individual. Meanwhile, the behavioral theory of motivation enunciates that reward is the motivating factor which compels the individual to excell in his/her career [54]. Relevant to this, every board member yearns to acquire the apex of the the hierarchical ladder. Hierarchical ranks are categorized into high, middle and low ranks [21]. Among this categorization, the low-rank board members are less enthusiastic about elevating their position in a hierarchical ladder as compared to middle rank [18]. Additionally, the high-rank board members are already manoeuvring to capture the top position. More precisely, Shah [27] assessed that medium hierarchical jumps in CEO succession do enhance the firms' growth. So, it can be assessed that if a higher authority forcefully turns over the CEO by replacing him/her with a high rank or middle-rank board member via hierarchical jumps, then organizational innovation will be augmented decisively.

H2a: Low hierarchical jumps (high-rank board members) in CEO succession is beneficial for both types of innovation (input $\mathcal{E}$ output)

H2b: Medium hierarchical jumps (medium rank board members) in CEO succession is useful for both types of innovation (input \& output) 


\section{Research Methodology}

The dependent variable is the innovation which has been measured by proxies (R\&D ratio and the number of patents). The objective of these proxies is to measure the impact of hierarchical jumps on both types of innovation (input \& output). The research and development (R\&D) ratio has been calculated by dividing R\&D expenses with the total assets [39]. Due to extensive missing data of R\&D expenses, the missing values have been replaced with " 0 " [17]. For robustness, the second proxy is Log (number of patents) which is also preferred by prior research [51,55] (as it also indicates the quality of innovation).

The hierarchical jump is the primary independent variable which has been formulated by analyzing the hierarchy order of board members of each company. Firstly, internal succession has been confirmed. Secondly, by counting the number of hierarchical positions, a successor has been elevated to CEO level; hierarchical jumps have been formulated [27]. Our hierarchical jump is assigned " 1 " and " 0 " otherwise. Moreover, none of the positions in the hierarchy have been multiplied with the dummy variable of hierarchical jump (which is crossed by the respective successor (see detail in Appendix A)). Mathematically

$$
\begin{aligned}
& H J_{i, t+1}=\left\{\begin{array}{rr}
1 & \text { Issc }>0, \text { and }\left(N_{p} H\right)_{i, t}>2 \\
0 & \text { otherwise }
\end{array}\right. \\
& H J_{i, t+1}^{*}=H J_{i, t+1} \times N_{p} H
\end{aligned}
$$

In Equation (1), following (Shah [27]), the hierarchical jump has been defined. For hierarchical Jumps, the first condition is "IsSC > 0" (internal succession (In CSMAR there are 12 categories of succession. Among them, $1=$ internal, while $2=$ external succession) must occur). Additionally, the second condition " $\left(N_{p} H\right)_{i, t}>2$ " elaborates that the number of the hierarchical position must be greater than "2", which means the newly incumbent successor (via hierarchical jump) must be at least the third position in hierarchical rank. In equation (2), " $H J_{i, t+1}^{*}$ " is the main independent variable of the hierarchical jump for panel regressions. It is the interaction term of the dummy variable and number of positions. The subscript " $i$ " indicates the different types of firms whereas " $t+1$ " is the time for the next year. Additionally, the hierarchical jump has been categorized into the low, medium and high level. Mathematically it can be written as

$$
\begin{aligned}
& H J_{i, t+1}=\sum\left(L H J_{i, t+1}+M H J_{i, t+1}+H H J_{i, t+1}\right) \text { such that } L H J_{i, t+1} \cap M H J_{i, t+1} \cap H H J_{i, t+1}=\varnothing \\
& \operatorname{LHJ}_{i, t+1}=\left\{\begin{array}{rr}
1 & \text { if } I_{s s c}>0,\left(N_{p} H\right)_{i, t} \leq U_{L} \\
0 & \text { otherwise }
\end{array}\right. \\
& L H J_{i, t+1}^{*}=L H J_{i, t} \times\left(N_{p} H\right)_{t} \\
& M H J_{i, t+1}=\left\{\begin{array}{rr}
1 & \text { if } I_{s s c}>0, U_{L}<\left(N_{p} H\right)_{i, t} \leq M_{L} \\
0 & \text { otherwise }
\end{array}\right. \\
& M H J_{i, t}^{*}=M H J_{i, t} \times\left(N_{p} H\right)_{t} \\
& H H J_{i, t+1}=\left\{\begin{array}{rrr}
1 & \text { if } I_{s s c}>0, & M_{L}<\left(N_{p} H\right)_{i, t} \leq L_{L} \\
0 & \text { otherwise }
\end{array}\right. \\
& H H J_{i, t}^{*}=H H J_{i, t} \times\left(N_{p} H\right)_{i, t}
\end{aligned}
$$

Equation (3) represents a hierarchical jump, which is the linear combination of three jumps and they are non-overlapping. In Equations (4), (6) and (8), $U_{L}, M_{L}$ and $L_{L}$ represent the upper, medium and lower interval of hierarchical positions of board members (see detail in Appendix A). 


\section{Control Variables}

This research analyses the effects of hierarchical jumps on innovation. In this connection, two types of control variables have been endorsed. One type of control variables is related to CEO succession, and another is related to innovation. In this regard, following the prior literature, we have preferred Duality [17], CEO age [46] and Degree [26]. These control variables indicate the specific attributes of the CEO successor, in which prior research has contemplated that CEOs' specific attributes orientate him/her towards innovation. Similarly, firm age [56], earnings per share and SOE [27] have also been included in our analysis. Additionally, following the extant literature, return on asset [4], leverage [53], Tobin Q [38], RDdummy [54] and Innovation intensity (R\&D expense/number of employees) have been preferred [57].

Individually, the newly incumbent CEOs confront the serve opposition by the upper echelon due to the execution of orthodox strategies which exacerbate the already miserable plight, and it results in his/her early elimination [54]. The crux of circulation of power theory also enunciates on the intensity of adaptability while pondering that if $\mathrm{CEO}$ remains stagnant while confronting the dynamic environment of organizations, then the contesters within the organizations escort him/her to the quick turnover [58]. Meanwhile, due to internal contestation, agency loss is also deterred which can assist the incumbent CEO successors to orientate towards organizational innovation vehemently.

The board members in organizational hierarchy are always desirous to elevate themselves within the hierarchical ladder. So, whenever CEO succession occurs, there can be severe confrontation among the members of the "upper echelon" [59] (especially the runner-up position holder board member). The specification of hierarchical positions is necessary for the firms' growth.

\section{Data Analysis}

The data for all listed Chinese companies on Shanghai and Shenzhen stock exchanges have been accumulated for the years (2012-2016), but due to missing data, the sample size has been squeezed to 1206 firms (4169 observations). Those firms which issue an "A" share are selected, as it is considered that these firms are under high surveillance of foreign investors [60]. China stock market \& accounting research (CSMAR) data source has been preferred, and they have already been endorsed by many scholars [60,61]. Financial data has been accumulated from the China stock market \& accounting research data source [8], while the company's profile has been analyzed to formulate the hierarchical jumps. Table 1 represents the number of hierarchical jumps which occurred during 2012-2016.

Table 1. Hierarchical Jumps.

\begin{tabular}{cccccc}
\hline Year & $\mathbf{2 0 1 3}$ & $\mathbf{2 0 1 4}$ & $\mathbf{2 0 1 5}$ & $\mathbf{2 0 1 6}$ & Total \\
\hline HJ & 36 & 81 & 83 & 83 & 283 \\
LHJ & 12 & 20 & 32 & 25 & 89 \\
MHJ & 8 & 18 & 15 & 11 & 52 \\
HHJ & 16 & 43 & 36 & 47 & 142 \\
\hline
\end{tabular}

Table 1 indicates the number of jumps which occurred during (2012-2016). It clarifies that maximum hierarchical jumps occurred during 2015 and 2016.

\section{Empirical Models}

The panel regression technique has been applied. Further, the 2sls instrumental variable technique has also been applied for the authentication of our results. Mathematically, panel regressions are represented by

$$
\operatorname{RDratio}_{i, t}=\beta_{0, t}+\beta_{1 i t} H J_{i, t}^{*}+\beta_{n i t} \sum_{n=2}^{12} Z_{n i t}+\delta_{i} \text { Inddum }_{i, t}+\delta_{i} \text { Yeardum }_{i, t}+\varepsilon_{i t}
$$




$$
\begin{gathered}
\text { RDratio }_{i, t}=\beta_{0, t}+\beta_{1 i t} L_{H} J_{i, t}^{*}+\beta_{2 i t} \text { MHJ }_{i, t}^{*}+\beta_{3 i t} H H J_{i, t}^{*}+\beta_{\text {nit }} \sum_{n=4}^{14} Z_{n i t}+\delta_{i} \text { Inddum }_{i, t}+\delta_{i} \text { Yeardum }_{i, t}+\varepsilon_{i t} \\
\text { LnPatents }_{i, t}=\beta_{0, t}+\beta_{1 i t} H J_{i, t}^{*}+\beta_{n i t} \sum_{n=2}^{12} Z_{n i t}+\delta_{i} \text { Inddum }_{i, t}+\delta_{i} \text { Yeardum }_{i, t}+\varepsilon_{i t} \\
\text { LnPatents }_{i, t}=\beta_{0, t}+\beta_{1 i t} L H J_{i, t}^{*}+\beta_{2 i t} M H J_{i, t}^{*}+\beta_{3 i t} H H J_{i, t}^{*}+\beta_{n i t} \sum_{n=4}^{14} Z_{n i t}+\delta_{i} \text { Inddum }_{i, t}+\delta_{i} \text { Yeardum }_{i, t}+\varepsilon_{i t}
\end{gathered}
$$

In Equations (10)-(13), “ $\beta_{\text {nit }} \sum_{n=2}^{12} Z_{\text {nit }}$ "represents the control variables (as in our regression, "11" control variables are included, so summation ends at 14$)$. Moreover, the industry dummy $\left(\delta_{i}\right.$ Inddum $\left._{i, t}\right)$ and year dummy $\left(\delta_{i} Y_{\text {eardum }}, t,{ }\right)$ have been included in the regressions following the extant literature.

\subsection{Empirical Results}

Table 2 depicts the descriptive statistics of all variables (dependent and control variables). Firstly, the fixed effect panel regression has been regressed. Through a reversal causality test, it has been confirmed that due to the existence of endogeneity, the results are spurious (as Appendix A hierarchical jumps and all its categorizations are insignificant). In order to eradicate the endogeneity, 2sls instrumental regression has been performed.

Table 2. Descriptive Statistics.

\begin{tabular}{cccccc}
\hline Variable & Observation & Mean & Std. Dev. & Min & Max \\
\hline LnPatents & 3228 & 3.721683 & 1.544164 & 0 & 10.1133 \\
RDratio & 4170 & 0.0042448 & 0.0106332 & 0 & 0.1536361 \\
HJ $^{*}$ & 4170 & 0.070024 & 1.152089 & 0 & 37 \\
LHJ $^{*}$ & 4170 & 0.0134293 & 0.4356526 & 0 & 20 \\
MHJ & 4170 & 0.0223022 & 0.7579317 & 0 & 37 \\
HHJ & 4170 & 0.0342926 & 0.7524002 & 0 & 28 \\
Fage & 4170 & 16.07818 & 4.65743 & 3 & 38 \\
SOE & 4103 & 0.3229344 & 0.4676549 & 0 & 1 \\
ROA & 4170 & 0.0411353 & 0.0500864 & -0.646402 & 0.27492 \\
EPS & 4170 & 0.3417625 & 0.5205464 & -3.996905 & 17.81979 \\
LEV & 4170 & 0.387106 & 0.2006879 & 0.007969 & 0.969384 \\
Degree & 4170 & 0.0275779 & 0.1637798 & 0 & 1 \\
AGE & 4170 & 0.028777 & 0.1671992 & 0 & 1 \\
ININT & 4169 & 7856.126 & 21557.72 & 0 & 227096.1 \\
Dual & 4133 & 0.2942173 & 0.4557452 & 0 & 1 \\
RDdummy & 4170 & 0.7328537 & 0.4425224 & 0 & 1 \\
TobinQ & 4170 & 2.709433 & 2.439901 & 0.097898 & 31.14391 \\
\hline
\end{tabular}

Table 2 shows the descriptive statistics. The minimum value of hierarchical jumps is " 0 " which means either hierarchical jump has not occurred or it can be another type of hierarchical jump (either low medium or high hierarchical jumps).

Table 3 describes the correlation which signifies that there is no threat of multicollinearity. Further, we have also determined VIF which is less than 3. So, there is no existence of multicollinearity among variables.

Table 3 has indicated that there is no threat of multicollinearity. 
Table 3. Correlation Matrix.

\begin{tabular}{|c|c|c|c|c|c|c|c|c|c|c|c|c|c|c|}
\hline & LnPatents & Rdratio & Hier Jumps & Fage & SOE & ROA & EPS & LEV & Degree & Age & INNIT & Dual & RDdummy & Tobin $Q$ \\
\hline LnPatents & 1.000 & & & & & & & & & & & & & \\
\hline Rdratio & 0.1237 & 1.000 & & & & & & & & & & & & \\
\hline HierJumps & -0.0237 & -0.0095 & 1.000 & & & & & & & & & & & \\
\hline Fage & 0.0385 & 0.0764 & 0.0274 & 1.000 & & & & & & & & & & \\
\hline SOE & 0.1039 & 0.2569 & 0.00443 & 0.1883 & 1.000 & & & & & & & & & \\
\hline ROA & 0.0096 & 0.0098 & -0.0200 & -0.0589 & -0.1835 & 1.000 & & & & & & & & \\
\hline EPS & 0.1158 & 0.00480 & 0.0008 & -0.000 & -0.0587 & 0.7461 & 1.000 & & & & & & & \\
\hline LEV & 0.2858 & 0.1684 & 0.0081 & 0.1710 & 0.3652 & -0.3419 & -0.1162 & 1.000 & & & & & & \\
\hline Degree & -0.0122 & -0.0070 & 0.1737 & 0.0541 & 0.0615 & -0.0249 & -0.0176 & -0.0039 & 1.000 & & & & & \\
\hline Age & 0.0398 & 0.0072 & 0.1623 & -0.0125 & 0.0028 & 0.0108 & 0.0181 & 0.0162 & 0.3731 & 1.000 & & & & \\
\hline ININT & 0.7843 & 0.1707 & -0.0079 & 0.0179 & 0.1794 & 0.0304 & 0.1100 & 0.2378 & -0.0077 & 0.0481 & 1.000 & & & \\
\hline Dual & -0.0 .551 & -0.1166 & -0.0054 & -0.0591 & -0.3110 & 0.0861 & 0.0116 & -0.1707 & -0.0258 & 0.0122 & -0.0925 & 1.000 & & \\
\hline RDdummy & -0.1512 & -0.7144 & -0.0047 & -0.0800 & -0.4076 & -0.0896 & -0.0029 & -0.3217 & 0.0216 & 0.219 & -0.1811 & 0.1985 & 1.000 & \\
\hline TobinQ & -0.1559 & -0.1319 & -0.0210 & -0.0175 & -0.2444 & 0.2695 & 0.0258 & -0.4624 & 0.0140 & -0.002 & -0.808 & 0.1444 & 0.2507 & 1.000 \\
\hline
\end{tabular}




\subsection{Robustness Check}

For robustness check, an instrumental variable (Hierarchical intensity) has been endorsed by following prior research [27]. Hierarchical intensity has been defined as an interaction term (number of hierarchical positions number of senior board members crossed). The hierarchical intensity has no direct relation with innovation, but it has a relation with hierarchical jumps. So, it satisfies the condition of becoming an instrumental variable. Mathematically

$$
\operatorname{HIN}_{i, t+1}=\left(N_{p} H\right)_{i, t} \times\left(n_{s} C\right)_{i, t}
$$

In Equation (14), " $\left(n_{S} C\right)_{i, t}$ " indicates the number of senior persons which have been crossed at that time " $t$ " for that particular firm " $i$ ". Table 4 shows that hierarchical jump has positively boosted innovation. Significantly, $9 \%$ of patents have increased while a minor enhancement in research and development $(R \& D)$ ratio is observed. One reason for this minor enhancement in the research and development ratio is due to missing data and also due to missing values (R\&D expense) which have been assigned " 0 " value. From this result, it can be evaluated that CEOs via hierarchical jumps are more concerned with the innovation output. One reason might be due to their vulnerable position. If they cannot perform spectacularly, they will depart soon. So, they emphasize emphatically on innovation output so that firms' performance may be boosted quickly. Firm age is highly positively significant for innovation output and innovation input [25]. Because of the competitive environment, it is challenging for the older firm to get more patents. So, firms do orientate themselves towards innovation input.

Additionally, return on assets and earnings per share are positively significant, which elaborates that firms with a high return on assets and earnings per share concentrate more on innovative activity. Meanwhile, leverage has shown negative significance for some patents and the research and development ratio. Manifestly, the firm has less loan burden concentrate more on adopting innovation activity.

Meanwhile, in Table 4, the variables, Dual, CEO (age) and Degree, are insignificant which illustrates that there is no need for specific attributes for the CEOs being appointed via hierarchical Jumps. Also, the variable SOE is also insignificant which means there is no difference between SOEs and non-SOEs (as hierarchical jumps affect both types). The reason behind this is due to government intervention among both types (state-owned enterprises and non-state-owned enterprises). Lastly, innovation intensity is positively related to both innovations input and output, which elaborates that with the more investment in $R \& D$, the number of patents will increase decisively.

Table 4 shows that $\mathrm{Hj}^{*}$ (hierarchical jumps) are positively significant for innovation (input/output) represented by "RDration and LnPatents." The variable LEV (leverage) has shown significance negatively while return on assets (ROA) and Fage (firm age) are highly significant with a positive sign elaborating that when a firm's performance is excellent for many years, then firms concentrate on their innovation (input and output) vigorously.

Tables 5 and 6 indicate that low and medium hierarchical jumps accelerate the innovation (input and output) while high hierarchical jumps are insignificant.

Table 5 clarifies that Low hierarchical jumps $\left(\mathrm{LHJ}^{*}\right.$ ) have boosted both types of innovation (input\& output). The results of the control' variables are almost the same as in Table 4.

Table 6 illustrates that the medium hierarchical jumps $\left(\mathrm{MJ}^{*}\right)$ enhance innovative activity. It has also been observed that the results of control variables are the same (as in Tables 4 and 5). Table 7 indicates that high hierarchical jumps (HHJ*) are insignificant for $\ln$ (patents). So, high hierarchical jumps are unnecessary for innovative activity. 
Table 4. 2sls Instrumental Regression (Impact of Hierarchical Jumps).

\begin{tabular}{|c|c|c|c|c|c|c|}
\hline \multirow{2}{*}{ Variables } & (1) & (2) & (3) & (4) & (5) & (6) \\
\hline & LnPatents & LnPatents & LnPatents & RDratio & RDratio & RDratio \\
\hline $\mathrm{HJ}^{*}$ & $\begin{array}{l}0.0939^{*} \\
(0.0566)\end{array}$ & $\begin{array}{l}0.0936^{*} \\
(0.0567)\end{array}$ & $\begin{array}{l}0.0933^{*} \\
(0.0561)\end{array}$ & $\begin{array}{l}0.000365^{*} \\
(0.000217)\end{array}$ & $\begin{array}{l}0.000367^{*} \\
(0.000217)\end{array}$ & $\begin{array}{l}0.000373 * \\
(0.000218)\end{array}$ \\
\hline Fage & $\begin{array}{l}0.0210^{* * *} \\
(0.00584)\end{array}$ & $\begin{array}{l}0.0216^{* * *} \\
(0.00585)\end{array}$ & $\begin{array}{l}0.021^{* * *} \\
(0.00583)\end{array}$ & $\begin{array}{c}6.77 \times 10^{-5 * * *} \\
\left(2.38 \times 10^{-5}\right)\end{array}$ & $\begin{array}{c}5.07 \times 10^{-5 * *} \\
\left(2.32 \times 10^{-5}\right)\end{array}$ & $\begin{array}{l}5.21 \times 10^{-5 * *} \\
\left(2.33 \times 10^{-5}\right)\end{array}$ \\
\hline SOE & $\begin{array}{c}0.104 \\
(0.0639)\end{array}$ & $\begin{array}{c}0.120^{*} \\
(0.0640)\end{array}$ & $\begin{array}{c}0.102 \\
(0.0638)\end{array}$ & $\begin{array}{c}-0.0731 * * * \\
(0.000261)\end{array}$ & & \\
\hline ROA & $\begin{array}{l}1.835^{* * *} \\
(0.709)\end{array}$ & $\begin{array}{l}2.000^{* * *} \\
(0.710)\end{array}$ & $\begin{array}{c}1.847^{* * *} \\
(0.709)\end{array}$ & $\begin{array}{l}0.00750 * * \\
(0.00300)\end{array}$ & $\begin{array}{l}0.00743^{* *} \\
(0.00294)\end{array}$ & \\
\hline EPS & $\begin{array}{l}0.309^{* * *} \\
(0.0611)\end{array}$ & $\begin{array}{l}0.315^{* * *} \\
(0.0613)\end{array}$ & $\begin{array}{l}0.309^{* * * *} \\
(0.0611)\end{array}$ & $\begin{array}{c}-7.26 \times 10^{-5} \\
(0.000267)\end{array}$ & $\begin{array}{c}-6.74 \times 10^{-5} \\
(0.000264)\end{array}$ & \\
\hline LEV & $\begin{array}{c}-1.675^{* * *} \\
(0.162) \\
\end{array}$ & $\begin{array}{c}-1.657^{* * *} \\
(0.162) \\
\end{array}$ & $\begin{array}{c}-1.677^{* * *} \\
(0.162)\end{array}$ & $\begin{array}{c}-0.00160^{* *} \\
(0.000661)\end{array}$ & $\begin{array}{c}-0.00196^{* * *} \\
(0.000639)\end{array}$ & $\begin{array}{c}-0.00249^{* * *} \\
(0.000616)\end{array}$ \\
\hline Degree & $\begin{array}{l}-0.0615 \\
(0.173)\end{array}$ & $\begin{array}{l}-0.0714 \\
(0.173)\end{array}$ & & $\begin{array}{c}0.000342 \\
(0.000709)\end{array}$ & $\begin{array}{c}0.000200 \\
(0.000652)\end{array}$ & $\begin{array}{c}0.000169 \\
(0.000653)\end{array}$ \\
\hline AGE & $\begin{array}{l}0.0845 \\
(0.160)\end{array}$ & $\begin{array}{c}0.119 \\
(0.161)\end{array}$ & & $\begin{array}{c}5.08 \mathrm{e}-05 \\
(0.000661) \\
\end{array}$ & & \\
\hline Dual & $\begin{array}{c}0.0101 \\
(0.0585)\end{array}$ & $\begin{array}{l}0.00774 \\
(0.0587) \\
\end{array}$ & $\begin{array}{c}0.0109 \\
(0.0585) \\
\end{array}$ & $\begin{array}{l}5.94 \times 10^{-05} \\
(0.000237)\end{array}$ & & \\
\hline ININT & $\begin{array}{c}6.04 \times 10^{-6 * * *} \\
\left(1.49 \times 10^{-6}\right)\end{array}$ & & $\begin{array}{l}6.08 \times 10^{6 * * *} \\
\left(1.49 \times 10^{6}\right)\end{array}$ & $\begin{array}{c}2.48 \times 10^{-7 * * *} \\
\left(6.04 \times 10^{9}\right)\end{array}$ & $\begin{array}{c}2.47 \times 10^{-7 * * *} \\
\left(5.93 \times 10^{-9}\right)\end{array}$ & $\begin{array}{c}2.49 \times 10^{-7 * * * *} \\
\left(5.92 \times 10^{-9}\right)\end{array}$ \\
\hline RDdummy & $\begin{array}{c}0.103 \\
(0.0786) \\
\end{array}$ & $\begin{array}{l}-0.0810 \\
(0.0640)\end{array}$ & $\begin{array}{c}0.105 \\
(0.0784) \\
\end{array}$ & $\begin{array}{c}-0.0098^{* * *} \\
(0.000320)\end{array}$ & $\begin{array}{c}-0.00946^{* * *} \\
(0.000306)\end{array}$ & $\begin{array}{c}-0.00946^{* * *} \\
(0.000306)\end{array}$ \\
\hline TobinQ & $\begin{array}{c}-0.0790 * * * \\
(0.0133)\end{array}$ & $\begin{array}{c}-0.0799^{* * *} \\
(0.0134)\end{array}$ & $\begin{array}{c}-0.079^{* * *} \\
(0.0133)\end{array}$ & $\begin{array}{l}-1.40 \times 10^{-5} \\
\left(5.43 \times 10^{-5}\right)\end{array}$ & $\begin{array}{l}-2.21 \times 10^{-6} \\
\left(5.34 \times 10^{5}\right)\end{array}$ & $\begin{array}{c}2.95 \times 10^{-5} \\
\left(5.21 \times 10^{-5}\right)\end{array}$ \\
\hline Industry dummy & Yes & Yes & Yes & Yes & Yes & Yes \\
\hline Year $_{\text {dummy }}$ & Yes & Yes & Yes & Yes & Yes & Yes \\
\hline Constant & $\begin{array}{l}1.677^{* * *} \\
(0.286)\end{array}$ & $\begin{array}{l}1.819^{* * *} \\
(0.284)\end{array}$ & $\begin{array}{c}1.677^{* * *} \\
(0.286)\end{array}$ & $\begin{array}{c}0.00774^{* * *} \\
(0.00107)\end{array}$ & $\begin{array}{c}0.00766^{* * *} \\
(0.00105)\end{array}$ & $\begin{array}{c}0.00796^{* * *} \\
(0.00105)\end{array}$ \\
\hline Observations & 3147 & 3148 & 3147 & 4066 & 4169 & 4169 \\
\hline R-squared & 0.165 & 0.161 & 0.165 & 0.634 & 0.632 & 0.631 \\
\hline
\end{tabular}


Table 5. 2sls Instrumental Regression (Impact of Low Hierarchical Jumps).

\begin{tabular}{|c|c|c|c|c|c|c|}
\hline \multirow{2}{*}{ Variables } & (1) & (2) & (3) & (4) & (5) & (6) \\
\hline & LnPatents & LnPatents & LnPatents & RDratio & RDratio & RDratio \\
\hline LHJ* $^{*}$ & $\begin{array}{l}1.290^{*} \\
(0.783)\end{array}$ & $\begin{array}{l}1.310^{*} \\
(0.794)\end{array}$ & $\begin{array}{l}1.312 * \\
(0.796)\end{array}$ & $\begin{array}{l}0.00315^{*} \\
(0.00189)\end{array}$ & $\begin{array}{l}0.00319^{*} \\
(0.00190)\end{array}$ & $\begin{array}{l}0.00319^{*} \\
(0.00190)\end{array}$ \\
\hline Fage & $\begin{array}{l}0.0156^{* *} \\
(0.00635) \\
\end{array}$ & $\begin{array}{l}0.0155^{* *} \\
(0.00634)\end{array}$ & $\begin{array}{l}0.0150^{* *} \\
(0.00627)\end{array}$ & $\begin{array}{l}4.94 \times 10^{-5 * *} \\
\left(2.40 \times 10^{-5}\right) \\
\end{array}$ & $\begin{array}{c}4.89 \times 10^{-5 * *} \\
\left(2.38 \times 10^{-5}\right) \\
\end{array}$ & $\begin{array}{l}4.89 \times 10^{-5} \text { ** } \\
\left(2.38 \times 10^{-5}\right) \\
\end{array}$ \\
\hline ROA & $\begin{array}{l}-0.131 \\
(0.739)\end{array}$ & $\begin{array}{l}-0.146 \\
(0.740)\end{array}$ & $\begin{array}{l}-0.179 \\
(0.742)\end{array}$ & $\begin{array}{c}0.00713 \text { ** } \\
(0.00303)\end{array}$ & $\begin{array}{c}0.00684^{* *} \\
(0.00301)\end{array}$ & $\begin{array}{c}0.00646^{* * * *} \\
(0.00225)\end{array}$ \\
\hline EPS & $\begin{array}{l}0.363^{* * * *} \\
(0.0657)\end{array}$ & $\begin{array}{l}0.363 * * * \\
(0.0658)\end{array}$ & $\begin{array}{l}0.363 * * * \\
(0.0658)\end{array}$ & $\begin{array}{c}-8.90 \times 10^{-5} \\
(0.000270)\end{array}$ & $\begin{array}{c}-5.07 \times 10^{-5} \\
(0.000269)\end{array}$ & \\
\hline LEV & & & & $\begin{array}{c}-0.0021 * * * \\
(0.000679)\end{array}$ & $\begin{array}{c}-0.0022 * * * \\
(0.000677)\end{array}$ & $\begin{array}{c}-0.0022 * * * \\
(0.000674)\end{array}$ \\
\hline Degree & $\begin{array}{c}0.157 \\
(0.188) \\
\end{array}$ & & & $\begin{array}{c}0.000226 \\
(0.000701) \\
\end{array}$ & & \\
\hline AGE & $\begin{array}{l}-0.316 \\
(0.308)\end{array}$ & $\begin{array}{l}-0.270 \\
(0.285)\end{array}$ & & $\begin{array}{l}-0.000524 \\
(0.000780)\end{array}$ & & \\
\hline Dual & $\begin{array}{l}-0.0445 \\
(0.0612)\end{array}$ & $\begin{array}{l}-0.0459 \\
(0.0614)\end{array}$ & $\begin{array}{l}-0.0492 \\
(0.0618)\end{array}$ & $\begin{array}{c}0.000125 \\
(0.000232)\end{array}$ & & \\
\hline RDINT & $\begin{array}{l}7.05 \times 10^{6 * * *} \\
\left(1.27 \times 10^{-6}\right) \\
\end{array}$ & $\begin{array}{l}7.04 \times 10^{6 * * *} \\
\left(1.27 \times 10^{-6}\right) \\
\end{array}$ & $\begin{array}{l}6.99 \times 10^{6 * * *} \\
\left(1.27 \times 10^{-6}\right) \\
\end{array}$ & $\begin{array}{l}2.47 \times 10^{7 * * *} \\
\left(6.10 \times 10^{-9}\right) \\
\end{array}$ & $\begin{array}{l}2.47 \times 10^{7 * * *} \\
\left(6.06 \times 10^{-9}\right)\end{array}$ & $\begin{array}{l}2.47 \times 10^{7 * * *} \\
\left(6.06 \times 10^{-9}\right)\end{array}$ \\
\hline RDdummy & & & & $\begin{array}{c}-0.0096^{* * *} \\
(0.000324)\end{array}$ & $\begin{array}{c}-0.0096^{* * *} \\
(0.000323)\end{array}$ & $\begin{array}{c}-0.0096^{* * *} \\
(0.000323)\end{array}$ \\
\hline TobinQ & $\begin{array}{c}-0.131^{* * *} \\
(0.0135)\end{array}$ & $\begin{array}{c}-0.131^{* * *} \\
(0.0135)\end{array}$ & $\begin{array}{c}-0.131^{* * *} \\
(0.0135)\end{array}$ & $\begin{array}{l}-1.96 \times 10^{-6} \\
\left(5.48 \times 10^{-5}\right) \\
\end{array}$ & $\begin{array}{c}2.15 \times 10^{-6} \\
\left(5.44 \times 10^{-5}\right) \\
\end{array}$ & $\begin{array}{c}3.52 \times 10^{-6} \\
\left(5.39 \times 10^{-5}\right) \\
\end{array}$ \\
\hline Industry $_{\text {dummy }}$ & Yes & Yes & Yes & Yes & Yes & Yes \\
\hline Year $_{\text {dummy }}$ & Yes & Yes & Yes & Yes & Yes & Yes \\
\hline Constant & $\begin{array}{l}2.171^{* * * *} \\
(0.346)\end{array}$ & $\begin{array}{c}2.165^{* * *} \\
(0.348)\end{array}$ & $\begin{array}{c}2.161 * * * \\
(0.351)\end{array}$ & $\begin{array}{c}0.00736^{* * * *} \\
(0.00109)\end{array}$ & $\begin{array}{c}0.00745^{* * * *} \\
(0.00108)\end{array}$ & $\begin{array}{c}0.00745^{* * *} \\
(0.00108)\end{array}$ \\
\hline Observations & 3195 & 3195 & 3195 & 4132 & 4169 & 4169 \\
\hline R-squared & 0.046 & 0.043 & 0.042 & 0.619 & 0.618 & 0.618 \\
\hline
\end{tabular}

Standard errors in parentheses ${ }^{* * *} p<0.01,{ }^{* *} p<0.05,{ }^{*} p<0.1$. 
Table 6. 2sls Instrumental Regression (Impact of Medium Hierarchical Jumps).

\begin{tabular}{|c|c|c|c|c|c|c|}
\hline \multirow{2}{*}{ Variables } & (1) & (2) & (3) & (4) & (5) & (6) \\
\hline & LnPatents & LnPatents & LnPatents & RDratio & RDratio & RDratio \\
\hline $\mathrm{MHJ}^{*}$ & $\begin{array}{l}0.167^{*} \\
(0.101)\end{array}$ & $\begin{array}{l}0.180^{*} \\
(0.103)\end{array}$ & $\begin{array}{l}0.179^{*} \\
(0.104)\end{array}$ & $\begin{array}{l}0.000839 * \\
(0.000496)\end{array}$ & $\begin{array}{l}0.000836^{*} \\
(0.000489)\end{array}$ & $\begin{array}{l}0.000837^{*} \\
(0.000490)\end{array}$ \\
\hline Fage & $\begin{array}{l}0.0197^{* * * *} \\
(0.00587) \\
\end{array}$ & $\begin{array}{l}0.0147^{* *} \\
(0.00596) \\
\end{array}$ & $\begin{array}{l}0.0130^{* *} \\
(0.00595)\end{array}$ & $\begin{array}{l}5.75 \times 10^{-5 * * *} \\
\left(2.35 \times 10^{-5}\right) \\
\end{array}$ & $\begin{array}{l}5.70 \times 10^{-5 * *} \\
\left(2.35 \times 10^{-5}\right) \\
\end{array}$ & $\begin{array}{r}5.55 \times 10^{-5 * *} \\
\left(2.33 \times 10^{-5}\right)\end{array}$ \\
\hline $\mathrm{SOE}$ & $\begin{array}{c}0.0984 \\
(0.0642)\end{array}$ & $\begin{array}{l}0.199^{* * *} \\
(0.0646)\end{array}$ & & & & \\
\hline ROA & $\begin{array}{c}1.834^{* * *} \\
(0.710)\end{array}$ & $\begin{array}{c}0.165 \\
(0.704)\end{array}$ & $\begin{array}{l}-0.0336 \\
(0.705)\end{array}$ & $\begin{array}{c}0.00766^{* *} \\
(0.00297)\end{array}$ & $\begin{array}{c}0.00771 * * * \\
(0.00297)\end{array}$ & $\begin{array}{c}0.00750 * * \\
(0.00295)\end{array}$ \\
\hline EPS & $\begin{array}{l}0.309^{* * *} \\
(0.0612)\end{array}$ & $\begin{array}{l}0.352^{* * *} \\
(0.0622)\end{array}$ & $\begin{array}{l}0.363 \text { *** } \\
(0.0627)\end{array}$ & $\begin{array}{l}-0.000117 \\
(0.000266)\end{array}$ & $\begin{array}{l}-0.000117 \\
(0.000265)\end{array}$ & $\begin{array}{c}-7.96 \times 10^{-5} \\
(0.000264)\end{array}$ \\
\hline LEV & $\begin{array}{c}-1.682^{* * *} \\
(0.162)\end{array}$ & & & $\begin{array}{c}-0.00186^{* * *} \\
(0.000645)\end{array}$ & $\begin{array}{c}-0.00185^{* * *} \\
(0.000645)\end{array}$ & $\begin{array}{c}-0.00194^{* * *} \\
(0.000641)\end{array}$ \\
\hline Degree & $\begin{array}{l}-0.141 \\
(0.193)\end{array}$ & $\begin{array}{l}-0.196 \\
(0.197)\end{array}$ & $\begin{array}{l}-0.134 \\
(0.194)\end{array}$ & $\begin{array}{c}-8.52 \times 10^{5} \\
(0.000763)\end{array}$ & & \\
\hline AGE & $\begin{array}{c}0.180 \\
(0.163)\end{array}$ & $\begin{array}{c}0.221 \\
(0.166)\end{array}$ & $\begin{array}{c}0.183 \\
(0.166)\end{array}$ & $\begin{array}{c}0.000405 \\
(0.000666)\end{array}$ & & \\
\hline Dual & $\begin{array}{l}0.00928 \\
(0.0586)\end{array}$ & $\begin{array}{c}0.0106 \\
(0.0596)\end{array}$ & $\begin{array}{l}-0.0196 \\
(0.0583)\end{array}$ & $\begin{array}{c}0.000165 \\
(0.000229)\end{array}$ & $\begin{array}{c}0.000169 \\
(0.000229)\end{array}$ & \\
\hline ININT & $\begin{array}{l}5.9 \times 10^{6 * * *} \\
\left(1.50 \times 10^{-6}\right)\end{array}$ & $\begin{array}{c}5.34 \times 10^{-6} \\
* * * \\
\left(1.52 \times 10^{-6}\right)\end{array}$ & $\begin{array}{c}5.14 \times 10^{-6 * * *} \\
\left(1.53 \times 10^{-6}\right)\end{array}$ & $\begin{array}{c}2.47 \times 10^{-7} * * * \\
\left(6.01 \times 10^{-9}\right)\end{array}$ & $\begin{array}{c}2.47 \times 10^{-7 * * *} \\
\left(6.00 \times 10^{-9}\right)\end{array}$ & $\begin{array}{r}2.47 \times 10^{-7 * * *} \\
\left(5.96 \times 10^{-9}\right)\end{array}$ \\
\hline RDdummy & $\begin{array}{c}0.0987 \\
(0.0787)\end{array}$ & $\begin{array}{l}-0.0380 \\
(0.0789)\end{array}$ & $\begin{array}{l}-0.115 \\
(0.0771)\end{array}$ & $\begin{array}{c}-0.00952 * * * \\
(0.000311)\end{array}$ & $\begin{array}{c}-0.00951^{* * *} \\
(0.000310)\end{array}$ & $\begin{array}{c}-0.00944^{* * *} \\
(0.000306)\end{array}$ \\
\hline TobinQ & $\begin{array}{c}-0.0772 * * * \\
(0.0133)\end{array}$ & $\begin{array}{l}-0.119^{* * *} \\
(0.0129)\end{array}$ & $\begin{array}{c}-0.130^{* * *} \\
(0.0129)\end{array}$ & $\begin{array}{l}-4.63 \times 10^{-8} \\
\left(5.39 \times 10^{-5}\right)\end{array}$ & $\begin{array}{l}-5.19 \times 10^{-7} \\
\left(5.39 \times 10^{-5}\right)\end{array}$ & $\begin{array}{r}4.05 \times 10^{-6} \\
\left(5.35 \times 10^{-5}\right)\end{array}$ \\
\hline Industry $_{\text {dummy }}$ & Yes & Yes & Yes & Yes & Yes & Yes \\
\hline Year $_{\text {dummy }}$ & Yes & Yes & Yes & Yes & Yes & Yes \\
\hline Constant & $\begin{array}{l}1.683^{* * *} \\
(0.286)\end{array}$ & $\begin{array}{l}2.436^{* * *} \\
(0.281)\end{array}$ & $\begin{array}{l}2.554^{* * *} \\
(0.283)\end{array}$ & $\begin{array}{c}0.00752 * * * \\
(0.00107)\end{array}$ & $\begin{array}{c}0.00752 * * * \\
(0.00107)\end{array}$ & $\begin{array}{c}0.00761^{* * *} \\
(0.00106)\end{array}$ \\
\hline Observations & 3147 & 3147 & 3195 & 4132 & 4132 & 4169 \\
\hline R-squared & 0.163 & 0.133 & 0.132 & 0.631 & 0.631 & 0.630 \\
\hline
\end{tabular}

Standard errors in parentheses ${ }^{* * *} p<0.01,{ }^{* *} p<0.05,^{*} p<0.1$ 
Table 7. 2sls Instrumental Regression (Impact of High Hierarchical Jumps)

\begin{tabular}{|c|c|c|c|c|c|c|}
\hline \multirow{2}{*}{ VARIABLES } & (1) & (2) & (3) & (4) & (5) & (6) \\
\hline & LnPatents & LnPatents & LnPatents & RDratio & RDratio & RDratio \\
\hline $\mathrm{HHj}^{*}$ & $\begin{array}{c}0.245 \\
(0.158)\end{array}$ & $\begin{array}{c}0.239 \\
(0.158)\end{array}$ & $\begin{array}{c}0.233 \\
(0.160)\end{array}$ & $\begin{array}{l}0.000826^{*} \\
(0.000489)\end{array}$ & $\begin{array}{l}0.000838^{*} \\
(0.000490)\end{array}$ & $\begin{array}{l}0.000827^{*} \\
(0.000491)\end{array}$ \\
\hline Fage & $\begin{array}{l}0.0225^{* * *} \\
(0.00594)\end{array}$ & $\begin{array}{l}0.0223^{* * *} \\
(0.00598)\end{array}$ & $\begin{array}{l}0.0218^{* * *} \\
(0.00594)\end{array}$ & $\begin{array}{c}6.24 \times 10^{-5 * * *} \\
\left(2.40 \times 10^{-5}\right) \\
\end{array}$ & $\begin{array}{c}6.25 \times 10^{-5 * * *} \\
\left(2.40 \times 10^{-5}\right) \\
\end{array}$ & $\begin{array}{c}5.81 \times 10^{-5 * *} \\
\left(2.39 \times 10^{-5}\right) \\
\end{array}$ \\
\hline SOE & $\begin{array}{c}0.114^{*} \\
(0.0619)\end{array}$ & $\begin{array}{c}0.117^{*} \\
(0.0621)\end{array}$ & & $\begin{array}{c}-0.000763^{* * *} \\
(0.000254)\end{array}$ & $\begin{array}{c}-0.000747^{* * *} \\
(0.000254)\end{array}$ & $\begin{array}{c}-0.000849^{* * *} \\
(0.000250)\end{array}$ \\
\hline ROA & $\begin{array}{c}1.932 * * * \\
(0.708) \\
\end{array}$ & $\begin{array}{c}4.140^{* * *} \\
(0.542)\end{array}$ & $\begin{array}{c}4.199 * * * \\
(0.540)\end{array}$ & $\begin{array}{l}0.00734^{* *} \\
(0.00299)\end{array}$ & $\begin{array}{c}0.00711^{* * *} \\
(0.00224) \\
\end{array}$ & $\begin{array}{c}0.00848^{* * *} \\
(0.00217)\end{array}$ \\
\hline EPS & $\begin{array}{l}0.295^{* * *} \\
(0.0611)\end{array}$ & & & $\begin{array}{c}-2.68 \times 10^{-5} \\
(0.000267)\end{array}$ & & \\
\hline LEV & $\begin{array}{c}-1.683^{* * *} \\
(0.162)\end{array}$ & $\begin{array}{c}-1.738^{* * *} \\
(0.162)\end{array}$ & $\begin{array}{c}-1.881^{* * *} \\
(0.160)\end{array}$ & $\begin{array}{c}-0.00159^{* *} \\
(0.000661)\end{array}$ & $\begin{array}{c}-0.00161^{* *} \\
(0.000659)\end{array}$ & \\
\hline Degree & & & & $\begin{array}{c}0.000625 \\
(0.000678)\end{array}$ & & \\
\hline AGE & & $\begin{array}{l}0.0228 \\
(0.163)\end{array}$ & & $\begin{array}{l}-0.000162 \\
(0.000678)\end{array}$ & & \\
\hline ININT & $\begin{array}{l}6.25 \times 10^{6} * * * \\
\left(1.48 \times 10^{-6}\right)\end{array}$ & $\begin{array}{l}6.9 \times 10^{-6 * * *} \\
\left(1.49 \times 10^{-6}\right) \\
\end{array}$ & $\begin{array}{l}6.1 \times 10^{6 * * *} \\
\left(1.49 \times 10^{-6}\right) \\
\end{array}$ & $\begin{array}{c}2.48 \times 10^{-7 * * *} \\
\left(6.01 \times 10^{-9}\right) \\
\end{array}$ & $\begin{array}{c}2.48 \times 10^{-7 * * *} \\
\left(6.01 \times 10^{-9}\right)\end{array}$ & $\begin{array}{c}2.48 \times 10^{-7} * * * \\
\left(6.01 \times 10^{-9}\right)\end{array}$ \\
\hline RDdummy & $\begin{array}{c}0.108 \\
(0.0784)\end{array}$ & $\begin{array}{c}0.111 \\
(0.0789)\end{array}$ & $\begin{array}{c}0.0683 \\
(0.0769)\end{array}$ & $\begin{array}{c}-0.00974^{* * *} \\
(0.000319)\end{array}$ & $\begin{array}{c}-0.00973^{* * *} \\
(0.000318)\end{array}$ & $\begin{array}{c}-0.00961^{* * *} \\
(0.000314)\end{array}$ \\
\hline TobinQ & $\begin{array}{c}-0.0812^{* * *} \\
(0.0135)\end{array}$ & $\begin{array}{c}-0.089^{* * *} \\
(0.0135)\end{array}$ & $\begin{array}{c}-0.093 * * * \\
(0.0134)\end{array}$ & $\begin{array}{l}-1.90 \times 10^{-5} \\
\left(5.45 \times 10^{-5}\right) \\
\end{array}$ & $\begin{array}{l}-1.91 \times 10^{-5} \\
\left(5.40 \times 10^{-5}\right) \\
\end{array}$ & $\begin{array}{c}2.08 \times 10^{-5} \\
\left(5.18 \times 10^{-5}\right)\end{array}$ \\
\hline Industry $_{\text {dummy }}$ & Yes & Yes & Yes & Yes & Yes & Yes \\
\hline Year $_{\text {dummy }}$ & Yes & Yes & Yes & Yes & Yes & Yes \\
\hline Constant & $\begin{array}{c}1.728^{* * *} \\
(0.285) \\
\end{array}$ & $\begin{array}{c}1.717^{* * *} \\
(0.286) \\
\end{array}$ & $\begin{array}{c}1.716^{* * *} \\
(0.288) \\
\end{array}$ & $\begin{array}{c}0.00792 * * * \\
(0.00107) \\
\end{array}$ & $\begin{array}{c}0.00792 * * * \\
(0.00107) \\
\end{array}$ & $\begin{array}{c}0.00728^{* * *} \\
(0.00104) \\
\end{array}$ \\
\hline Observations & 3178 & 3178 & 3227 & 4102 & 4102 & 4102 \\
\hline R-squared & 0.157 & 0.152 & 0.156 & 0.631 & 0.631 & 0.631 \\
\hline
\end{tabular}

Standard errors in parentheses ${ }^{* * *} p<0.01,{ }^{* *} p<0.05,{ }^{*} p<0.1$. 


\section{Conclusions}

Corporate governance is the backbone of the organization which assists in confronting the dynamic environment of the business. The advanced economy has consolidated its corporate structure so that its organizations are booming irresistibly. Specifically, corporate governance concentrates on innovation with sustainable growth. Innovation is a two-edged sword which assists with sustainability via competitive advantage but sometimes can be detrimental for firms' growth. Innovation not only boosts the working efficiency but also acts as a catalyst for enhancing the firms' growth. The Chinese government has launched the policy "Imitation to innovation" which has orientated the Chinese organizations to concentrate intensely on innovative activity within organizations. According to the organizational structure, the role of CEOs is pivotal and can either enhance or decelerate the innovative activity within the organization. Interestingly, prior research has unveiled that when a new CEO successor is appointed, the momentum of innovative activity remains irresistible. Relevant to this, current research has concluded the same results.

Firstly, the hierarchical jumps have been formulated by analyzing the internal CEOs succession. It has also been observed that CEOs succession via hierarchical jumps boosts both types of innovation (input/output). Significantly, the incumbent CEO successors via hierarchical jumps incline towards innovation output decisively. Moreover, to comprehend with deep insight, the hierarchical jumps are categorized into low, medium and high level, signifying that low and medium hierarchical jumps in CEO successions are advantageous for firm's innovation while high hierarchical jumps in CEO successions are unnecessary. Additionally, mature firms having a high return on assets and earnings per share prefer to enhance the intensity of innovation input and output. Moreover, firms with less loan burden are also motivated towards innovative activity. Lastly, hierarchical jumps in CEO successors have no relationship with the attributes of CEOs (age, education and duality).

\subsection{Study Justification}

Corporate governance can maintain the sustainability of firms while adopting an innovation. Western economies have developed an innovative corporate culture which has boosted the firms' growth. Following the advanced economy, Chinese organizations are also endeavoring to adopt innovative strategies. Specifically, Chinese organizations are categorized into SOEs and non-SOEs, and among these organizations, CEOs are politically connected [13]. In this regard, the government is controlling both types of organizations. So, whenever CEOs are appointed via hierarchical jumps, they are eager to enhance the firms' performance. Consequently, they execute such strategies which invigorate the organizational innovation. Moreover, the board members who are at the position of the upper or middle level are always eager to reach the top level. So, whenever they are elevated via a hierarchical jump to CEO position, they endeavor at their full extent to ameliorate the economic situation of the firms. In this connection, they escalate the innovative activities within the organization. Study results have also manifested that medium hierarchical jumps in CEO succession have accelerated the innovation output in comparison to the low hierarchical jumps. The reason behind this is the enthusiasm of medium level board members which has been intensified while confronting with the vulnerable hierarchical position. This threat of vulnerability compels them to be more efficient. For the sake of survival, they are vigilant and more conscious about innovation as compared to high-rank board members. Our results are supported by the prior research of Shah [27] which revealed that medium hierarchical jumps are necessary for firms' growth.

\subsection{Study Limitations}

Though we have contributed via introducing a new concept of hierarchical jumps, still there are certain limitations. Firstly, this study has not observed the impact of gender difference among hierarchical jumps in CEO successions. Future research can be conducted while analyzing the gender difference. Secondly, it can also be investigated whether hierarchical jumps mitigate the organizational 
risk or not. Lastly, hierarchical jumps can also be analyzed for the companies listed on the Hong Kong stock exchange.

Author Contributions: Conceptualization, M.S. and S.G.M.S.; Data curation, S.G.M.S. and Z.F.; Formal analysis, M.S. and S.G.M.S.; Funding acquisition, W.Q.; Methodology, S.G.M.S.; Project administration, M.S. and W.Q.; Resources, W.Q.; Software, S.G.M.S.; Supervision, W.Q.; Writing—original draft, S.G.M.S.; Writing—review \& editing, W.Q. and M.S. All the authors confirm contribution to study conception and design, data collection, analysis and interpretation of results, and manuscript preparation. All authors reviewed the results and approved the final version of the manuscript.

Funding: This study was supported by The National Social Science Fund of China (Grant No.18BGL129).

Conflicts of Interest: The authors declare no conflict of interest.

\section{Appendix A}

Table A1. Fixed Effect Panel Regression (Impact of Hierarchical Jumps).

\begin{tabular}{|c|c|c|c|c|c|}
\hline \multirow{2}{*}{ Variables } & (1) & (2) & (3) & (4) & (5) \\
\hline & LnPatents & LnPatents & LnPatents & RDratio & RDratio \\
\hline $\mathrm{HJ}^{*}$ & $\begin{array}{c}0.0130 \\
(0.0166)\end{array}$ & $\begin{array}{c}0.0133 \\
(0.0166)\end{array}$ & $\begin{array}{c}0.0140 \\
(0.0166)\end{array}$ & $\begin{array}{l}-1.20 \times 10^{-5} \\
\left(4.64 \times 10^{-5}\right)\end{array}$ & $\begin{array}{l}-8.95 \times 10^{-6} \\
\left(4.63 \times 10^{-5}\right)\end{array}$ \\
\hline Fage & $\begin{array}{l}0.216^{* * *} \\
(0.0141)\end{array}$ & $\begin{array}{l}0.216^{* * *} \\
(0.0141)\end{array}$ & $\begin{array}{l}0.219 * * * \\
(0.0140)\end{array}$ & $\begin{array}{c}-0.000240^{* * *} \\
\left(3.86 \times 10^{-5}\right)\end{array}$ & $\begin{array}{l}-0.000233^{* * *} \\
\left(3.83 \times 10^{-5}\right)\end{array}$ \\
\hline SOE & $\begin{array}{l}0.0633 \\
(0.211)\end{array}$ & $\begin{array}{l}0.0630 \\
(0.211)\end{array}$ & $\begin{array}{l}0.0963 \\
(0.210)\end{array}$ & $\begin{array}{c}0.000284 \\
(0.000616)\end{array}$ & $\begin{array}{c}0.000307 \\
(0.000614)\end{array}$ \\
\hline ROA & $\begin{array}{l}-0.984 \\
(0.692)\end{array}$ & $\begin{array}{l}-0.981 \\
(0.691)\end{array}$ & $\begin{array}{l}-0.927 \\
(0.691)\end{array}$ & $\begin{array}{l}-0.00223 \\
(0.00182)\end{array}$ & $\begin{array}{l}-0.00208 \\
(0.00181)\end{array}$ \\
\hline EPS & $\begin{array}{l}0.123 \text { ** } \\
(0.0564)\end{array}$ & $\begin{array}{l}0.123 \text { ** } \\
(0.0563)\end{array}$ & $\begin{array}{l}0.128 \text { ** } \\
(0.0563)\end{array}$ & $\begin{array}{c}-5.26 \times 10^{-5} \\
(0.000147)\end{array}$ & $\begin{array}{c}-5.77 \times 10^{-5} \\
(0.000146)\end{array}$ \\
\hline LEV & $\begin{array}{c}0.533^{* *} \\
(0.251)\end{array}$ & $\begin{array}{l}0.537 * * \\
(0.251)\end{array}$ & $\begin{array}{l}0.505 * * \\
(0.251)\end{array}$ & $\begin{array}{c}7.74 \times 10^{-5} \\
(0.000674)\end{array}$ & $\begin{array}{c}5.64 \times 10^{-5} \\
(0.000670)\end{array}$ \\
\hline Degree & $\begin{array}{c}-0.00641 \\
(0.127)\end{array}$ & $\begin{array}{c}0.00650 \\
(0.118)\end{array}$ & $\begin{array}{c}0.00653 \\
(0.119)\end{array}$ & $\begin{array}{c}8.28 \times 10^{-5} \\
(0.000342)\end{array}$ & $\begin{array}{c}0.000173 \\
(0.000318)\end{array}$ \\
\hline AGE & $\begin{array}{l}0.0345 \\
(0.119)\end{array}$ & & & $\begin{array}{c}0.000293 \\
(0.000323)\end{array}$ & \\
\hline Dual & $\begin{array}{l}0.00346 \\
(0.0764)\end{array}$ & $\begin{array}{l}0.00382 \\
(0.0764)\end{array}$ & $\begin{array}{c}-0.000493 \\
(0.0764)\end{array}$ & $\begin{array}{l}-0.000245 \\
(0.000200)\end{array}$ & \\
\hline RDINT & $\begin{array}{l}6.27 \times 10^{-6 * *} \\
\left(2.92 \times 10^{-6}\right)\end{array}$ & $\begin{array}{l}6.31 \times 10^{-6 * *} \\
\left(2.92 \times 10^{-6}\right)\end{array}$ & & $\begin{array}{c}2.17 \times 10^{-7} * * * \\
\left(7.83 \times 10^{-9}\right)\end{array}$ & $\begin{array}{c}2.14 \times 10^{-7} * * * \\
\left(7.70 \times 10^{-9}\right)\end{array}$ \\
\hline RDdummy & $\begin{array}{c}0.133 \\
(0.301)\end{array}$ & $\begin{array}{c}0.135 \\
(0.301)\end{array}$ & $\begin{array}{c}-0.0805 \\
(0.284)\end{array}$ & $\begin{array}{c}-0.0161^{* * *} \\
(0.000792)\end{array}$ & $\begin{array}{c}-0.0162^{* * *} \\
(0.000789)\end{array}$ \\
\hline TobinQ & $\begin{array}{l}-0.0182 \\
(0.0132)\end{array}$ & $\begin{array}{l}-0.0183 \\
(0.0132)\end{array}$ & $\begin{array}{l}-0.0191 \\
(0.0132)\end{array}$ & $\begin{array}{l}6.24 \times 10^{-5 *} \\
\left(3.40 \times 10^{-5}\right)\end{array}$ & $\begin{array}{l}6.37 \times 10^{-5 *} \\
\left(3.39 \times 10^{-5}\right)\end{array}$ \\
\hline Industry $_{\text {dummy }}$ & Yes & Yes & Yes & Yes & Yes \\
\hline Year $_{\text {dummy }}$ & Yes & Yes & Yes & Yes & Yes \\
\hline Constant & $\begin{array}{c}-0.0798 \\
(0.327)\end{array}$ & $\begin{array}{c}-0.0858 \\
(0.326)\end{array}$ & $\begin{array}{l}0.0657 \\
(0.319)\end{array}$ & $\begin{array}{l}0.0182 * * * \\
(0.000870)\end{array}$ & $\begin{array}{l}0.0181 * * * \\
(0.000860)\end{array}$ \\
\hline Observations & 3147 & 3147 & 3148 & 4066 & 4102 \\
\hline R-squared & 0.196 & 0.196 & 0.194 & 0.392 & 0.389 \\
\hline $\begin{array}{l}\text { Number of } \\
\text { companies }\end{array}$ & 1109 & 1109 & 1109 & 1200 & 1206 \\
\hline
\end{tabular}

Standard errors in parentheses ${ }^{* * *} p<0.01,{ }^{* *} p<0.05,{ }^{*} p<0.1$.

Table A1 clarifies that hierarchical jumps are insignificant. The reason behind this is the presence of endogeneity. 
Table A2. Fixed Effect Regression (All Categorization of Hierarchical Jumps).

\begin{tabular}{|c|c|c|c|c|c|}
\hline \multirow{2}{*}{ Variables } & (1) & (2) & (3) & (4) & (5) \\
\hline & LnPatents & LnPatents & LnPatents & RDratio & RDratio \\
\hline \multirow{2}{*}{$\mathrm{LHJ}^{*}$} & -0.0436 & -0.0402 & -0.0361 & $2.60 \times 10^{-5}$ & $3.93 \times 10^{-5}$ \\
\hline & $(0.0578)$ & $(0.0570)$ & $(0.0570)$ & (0.000117) & $(0.000116)$ \\
\hline \multirow{2}{*}{$\mathrm{MHJ}^{*}$} & 0.00507 & 0.00485 & 0.00494 & $-1.96 \times 10^{-5}$ & $-1.90 \times 10^{-5}$ \\
\hline & $(0.0220)$ & $(0.0219)$ & $(0.0219)$ & $\left(6.91 \times 10^{-5}\right)$ & $\left(6.89 \times 10^{-5}\right)$ \\
\hline \multirow{2}{*}{$\mathrm{HHJ}^{*}$} & 0.0398 & 0.0407 & 0.0386 & $-1.81 \times 10^{-5}$ & $-1.27 \times 10^{-5}$ \\
\hline & $(0.0284)$ & $(0.0283)$ & $(0.0283)$ & $\left(7.36 \times 10^{-5}\right)$ & $\left(7.34 \times 10^{-5}\right)$ \\
\hline \multirow{2}{*}{ Fage } & $0.216^{* * *}$ & $0.216^{* * *}$ & $0.221^{* * *}$ & $-0.000240^{* * *}$ & $-0.000237^{* * *}$ \\
\hline & $(0.0141)$ & $(0.0141)$ & $(0.0139)$ & $\left(3.86 \times 10^{-5}\right)$ & $\left(3.85 \times 10^{-5}\right)$ \\
\hline \multirow{2}{*}{ SOE } & 0.0628 & 0.0627 & 0.0657 & 0.000284 & 0.000285 \\
\hline & $(0.211)$ & $(0.211)$ & $(0.211)$ & $(0.000616)$ & $(0.000616)$ \\
\hline \multirow{2}{*}{ ROA } & -0.995 & -0.992 & $-1.240^{*}$ & -0.00224 & -0.00222 \\
\hline & $(0.692)$ & $(0.691)$ & $(0.683)$ & $(0.00182)$ & $(0.00182)$ \\
\hline \multirow{2}{*}{ EPS } & $0.123^{* *}$ & $0.123 * *$ & $0.128 * *$ & $-5.22 \times 10^{-5}$ & $-5.22 \times 10^{-5}$ \\
\hline & $(0.0564)$ & $(0.0563)$ & $(0.0563)$ & (0.000147) & $(0.000147)$ \\
\hline \multirow{2}{*}{ LEV } & 0.548 ** & $0.553 * *$ & & $7.30 \times 10^{-5}$ & 0.000113 \\
\hline & $(0.252)$ & $(0.251)$ & & $(0.000675)$ & $(0.000674)$ \\
\hline \multirow{2}{*}{ Degree } & -0.00888 & & & $7.98 \times 10^{-5}$ & \\
\hline & $(0.127)$ & & & $(0.000342)$ & \\
\hline \multirow{2}{*}{ AGE } & 0.0429 & & & 0.000286 & \\
\hline & $(0.120)$ & & & $(0.000324)$ & \\
\hline \multirow{2}{*}{ Dual } & 0.00516 & 0.00570 & 0.00412 & -0.000245 & -0.000240 \\
\hline & $(0.0764)$ & $(0.0764)$ & $(0.0764)$ & $(0.000200)$ & $(0.000200)$ \\
\hline \multirow{2}{*}{ RDINT } & $6.23 \times 10^{-6 * *}$ & $6.28 \times 10^{-6 * *}$ & $5.92 \times 10^{-6 * *}$ & $2.17 \times 10^{-7 * * *}$ & $2.17 \times 10^{-7 * * *}$ \\
\hline & $\left(2.92 \times 10^{-6}\right)$ & $\left(2.92 \times 10^{-6}\right)$ & $\left(2.91 \times 10^{-6}\right)$ & $\left(7.83 \times 10^{-9}\right)$ & $\left(7.82 \times 10^{-9}\right)$ \\
\hline \multirow{2}{*}{ RDdummy } & 0.132 & 0.135 & 0.146 & $-0.0161^{* * *}$ & $-0.0161^{* * *}$ \\
\hline & $(0.301)$ & $(0.301)$ & $(0.301)$ & $(0.000792)$ & $(0.000792)$ \\
\hline \multirow{2}{*}{ TobinQB } & -0.0186 & -0.0188 & -0.0188 & $6.24 \times 10^{-5 *}$ & $6.20 \times 10^{-5 *}$ \\
\hline & $(0.0132)$ & $(0.0132)$ & $(0.0132)$ & $\left(3.40 \times 10^{-5}\right)$ & $\left(3.40 \times 10^{5}\right)$ \\
\hline Indusrty $_{\text {dummy }}$ & Yes & Yes & Yes & Yes & Yes \\
\hline Year dummy & Yes & Yes & Yes & Yes & Yes \\
\hline \multirow{2}{*}{ Constant } & -0.0848 & -0.0931 & 0.0473 & $0.0182 * * *$ & $0.0181 * * *$ \\
\hline & $(0.327)$ & $(0.326)$ & $(0.320)$ & $(0.000871)$ & $(0.000867)$ \\
\hline Observations & 3147 & 3147 & 3147 & 4066 & 4066 \\
\hline R-squared & 0.197 & 0.197 & 0.195 & 0.392 & 0.392 \\
\hline $\begin{array}{l}\text { Number of } \\
\text { companies }\end{array}$ & 1109 & 1109 & 1109 & 1200 & 1200 \\
\hline
\end{tabular}

Table A2 indicates the insignificant results of all types of hierarchical jumps due to the endogeneity problem. 
Table A3. How to Measure Hierarchical Jumps and Hierarchical Intensity.

\begin{tabular}{cccccc}
\hline Code & Year & Name & Designation & Age & Education \\
\hline 600432 & 2015 & 吴术 (Wu Shu) & CEO & 50 & \\
600432 & 2015 & 徐广平 & Director & 60 & \\
600432 & 2015 & 于然波 & Director & 51 & \\
600432 & 2015 & 李景峰 & Director & 50 & \\
600432 & 2015 & 王若冰(Wang Ruo Bing) & Independent director & 46 & \\
600432 & 2015 & 马忠全 & Director & 50 & \\
600432 & 2015 & 毛志宏 & Independent Director & 55 & \\
600432 & 2015 & 胡静波 & Independent Director & 46 & Professor \\
600432 & 2015 & 李明 & Independent Director & 55 & \\
600432 & 2015 & 王健 & Independent Director & 54 & \\
600432 & 2015 & 宿跃德 & Supervisor & 59 & \\
600432 & 2015 & 李淳南 & Supervisor & 58 & \\
600432 & 2015 & 李德君 & Supervisor & 57 & \\
600432 & 2015 & 刘俊梅 & Staff supervisor & 51 & \\
600432 & 2015 & 米海祥 & Vice GM & 53 & \\
600432 & 2015 & 王行龙 & Vice GM & 48 & \\
600432 & 2016 & 王若冰 (Wang Ruo Bing) & CEO & 47 & \\
600432 & 2016 & 徐广平 & Director & 61 & \\
\hline
\end{tabular}

Table A3 indicates the listed Chinese company with stock code (600432). The hierarchical jump has been measured for the year 2016. Its board size is 16 . For this board size, $U_{L}=[1,5], M_{L}=[6,11]$ and $L_{L}=[7,16]$. Mr. Shu Wu was the CEO in 2015. When succession occurred, the independent director (Mr. Bing Wang Ruo) was appointed as a CEO via hierarchical Jump, who was allocated at fifth position $\left(N_{p} H\right)_{i, t}=5$ ) in hierarchical order in 2015. Firstly, it is a hierarchical jump so, from Equation (1).

Equation (A1)

$$
H J_{i, t+1}=1
$$

Further from Equation (A2)

$$
H J_{i, t+1}^{*}=H J_{i, t+1} \times N_{p} H=1 \times 5=5
$$

Moreover, it is a low hierarchical jump. So, from Equation (A3)

$$
L H J_{i, t+1}=\left\{\begin{array}{rrr}
1 & \text { if } I_{s s c}>0, & \left(N_{p} H\right)_{i, t} \leq U_{L} \\
0 & \text { otherwise }
\end{array}\right.
$$

In the above equation $U_{L}=[1,5]$ and $\left(N_{p} H\right)_{t}=5$ (as Mr. Bing Wang Ruo is at 5th hierarchical order). So, Lower hierarchical jump is calculated as $L H J_{i, t+1}^{*}=L H J_{i, t} \times\left(N_{p} H\right)_{t}=1 \times 5=5$.

Lastly, Hierarchical Intensity can be determined as follow:

$H_{I N} N_{i, t+1}=\left(N_{p} H\right)_{i, t} \times\left(n_{s} C\right)_{i, t}=5 \times 4=20$ (Because Mr. Bing Wang Ruo has crossed 4 senior board members).

\section{References}

1. la Porta, R.; Lopez-de-Silanes, F.; Shleifer, A.; Vishny, R. Investor protection and corporate valuation. J. Financ. 2002, 57, 1147-1170. [CrossRef]

2. Gillan, S.L. Recent Developments in Corporate Governance: An Overview. J. Corp. Financ. 2006, 12, 381-402. [CrossRef]

3. Damanpour, F.; Aravind, D. Managerial innovation: Conceptions, processes and antecedents. Manag. Organ. Rev. 2012, 8, 423-454. [CrossRef] 
4. Aarstad, J.; Kvitastein, O.A.; Jakobsen, S.E. Related and unrelated variety as regional drivers of enterprise productivity and innovation: A multilevel study. Res. Policy 2016, 45, 844-856. [CrossRef]

5. Haß, L.H.; Johan, S.; Schweizer, D. Is corporate governance in China related to performance persistence? J. Bus. Ethics 2016, 134, 575-592. [CrossRef]

6. Barney, J.B.; Ketchen, D.J.; Wright, M. The future of resource-based theory: Revitalization or decline? J. Manag. 2011, 37, 1299-1315. [CrossRef]

7. Ou, Y.; Waldman, D.A.; Peterson, S.J. Do humble CEOs matter? An examination of CEO humility and firm outcomes. J. Manag. 2018, 44, 1147-1173. [CrossRef]

8. Zhu, J.; Ye, K.; Tucker, J.W.; Chan, K.J.C. Board hierarchy, independent directors, and firm value: Evidence from China. J. Corp. Financ. 2016, 41, 262-279. [CrossRef]

9. Xu, J.; Zhang, Y. Family CEO and information disclosure: Evidence from China. Financ. Res. Lett. 2018, 26, 169-176. [CrossRef]

10. Young, M.N.; Peng, M.W.; Ahlstrom, D.; Bruton, G.D.; Jiang, Y. Corporate governance in emerging economies: A review of the principal-principal perspective: Review paper. J. Manag. Stud. 2008, 45, 196-220. [CrossRef]

11. Li, K.; Wang, T.; Cheung, Y.L.; Jiang, P. Privatization and risk sharing: Evidence from the split share structure reform in China. Rev. Financ. Stud. 2011, 24, 2499-2525. [CrossRef]

12. Jiang, F.; Kim, K.A. Corporate governance in China: A modern perspective. J. Corp. Financ. 2015, 32, $190-216$. [CrossRef]

13. Wu, H.; Li, S.; Ying, S.X.; Chen, X. Politically connected CEOs, firm performance, and CEO pay. J. Bus. Res. 2018, 91, 169-180. [CrossRef]

14. Eisfeldt, L.; Kuhnen, C.M. CEO turnover in a competitive assignment framework. J. Financ. Econ. 2013, 109, 351-372. [CrossRef]

15. Jenter, D.; Kanaan, F. CEO turnover and relative performance evaluation. J. Financ. 2015, 70, $2155-2184$. [CrossRef]

16. Galasso, A.; Simcoe, T.S. CEO overconfidence and innovation. Manag. Sci. 2011, 57, 1469-1484. [CrossRef]

17. Faleye, O.; Kovacs, T.; Venkateswaran, A. Do better-connected CEOs innovate more? J. Financ. Quant. Anal. 2014, 49, 957-1003. [CrossRef]

18. Farag, H.; Mallin, C. The influence of CEO demographic characteristics on corporate risk-taking: Evidence from Chinese IPOs. Eur. J. Financ. 2018, 24, 1528-1551. [CrossRef]

19. Mao, C.X.; Zhang, C. Managerial Risk-Taking Incentive and Firm Innovation: Evidence from FAS $123 R$. J. Financ. Quant. Anal. 2018, 53, 867-898. [CrossRef]

20. Crossan, M.M.; Apaydin, M. A multi-dimensional framework of organizational innovation: A systematic review of the literature. J. Manag. Stud. 2010, 47, 1154-1191. [CrossRef]

21. Hu, M.C.; Mathews, J.A. China's national innovative capacity. Res. Policy 2008, 37, 1465-1479. [CrossRef]

22. Wu, J.; Ma, L.; Yang, Y. Innovation in the Chinese public sector: Typology and distribution. Public Adm. 2013, 91, 347-365. [CrossRef]

23. Shu, C.; Wang, Q.; Gao, S.; Liu, C. Firm patenting, innovations, and government institutional support as a double-edged sword. J. Prod. Innov. Manag. 2015, 32, 290-305. [CrossRef]

24. He, J.; Huang, Z. Board informal hierarchy and firm financial performance: Exploring a tacit structure guiding boardroom interactions. Acad. Manag. J. 2011, 54, 1119-1139. [CrossRef]

25. Tien, C.; Chen, C.N. Myth or reality? Assessing the moderating role of CEO compensation on the momentum of innovation in R\&D. Int. J. Hum. Resour. Manag. 2012, 23, 2763-2784.

26. Wong, Y.J.; Chen, L.Y. Does the origin of a succession CEO matter in the market value of innovation? Disentangling the origin of internal CEOs. Can. J. Adm. Sci. 2018, 35, 136-145. [CrossRef]

27. Shah, S.G.M.; Tang, M.; Sarfraz, M.; Fareed, Z. The aftermath of CEO succession via hierarchical jumps on firm performance and agency cost: Evidence from Chinese firms. Appl. Econ. Lett. 2019. [CrossRef]

28. Phillips, D.J.; Zuckerman, E.W. Middle-status conformity: Theoretical restatement and empirical demonstration in two markets. Am. J. Sociol. 2001, 107, 379-429. [CrossRef]

29. Kim, K.A.; Nofsinger, J.R.; Mohr, D.J. Corporate Governance, 3rd ed.; Pearson (KNM): London, UK, 2010.

30. Cheung, Y.L.; Jiang, P.; Limpaphayom, P.; Lu, T. Corporate governance in China: A step forward. Eur. Financ. Manag. 2010, 16, 94-123. [CrossRef] 
31. Yang, D.; Jiao, H.; Buckland, R. The determinants of financial fraud in Chinese firms: Does corporate governance as an institutional innovation matter? Technol. Forecast. Soc. Chang. 2017, 125, 309-320. [CrossRef]

32. Conyon, M.J.; He, L. Executive compensation and corporate governance in China. J. Corp. Financ. 2011, 17, 1158-1175. [CrossRef]

33. Li, H.; Li, J. Top management team conflict and entrepreneurial strategy making in China. Asia Pac. J. Manag. 2009, 26, 263-283. [CrossRef]

34. Firth, M.; Wong, S.M.L.; Yang, Y. The double-edged sword of CEO/chairperson duality in corporatized state-owned firms: evidence from top management turnover in China. J. Manag. Gov. 2014, 18, 207-244. [CrossRef]

35. He, J.; Tian, X. Finance and Corporate Innovation: A Survey. Asia-Pac. J. Financ. Stud. 2018, 47, $165-212$. [CrossRef]

36. Zhou, Y.; Hong, Y.; Liu, J. Internal Commitment or External Collaboration? The Impact of Human Resource Management Systems on Firm Innovation and Performance. Hum. Resour. Manag. 2013, 52, 263-288. [CrossRef]

37. Zhang, G.; Tang, C. How could firm's internal R\&D collaboration bring more innovation? Technol. Forecast. Soc. Chang. 2017, 125, 299-308.

38. Dong, J.; Gou, Y.N. Corporate governance structure, managerial discretion, and the R\&D investment in China. Int. Rev. Econ. Financ. 2010, 19, 180-188.

39. Hirshleifer, D.; Low, A.; Teoh, S.H. Are Overconfident CEOs Better Innovators? J. Financ. 2012, 67, 1457-1498. [CrossRef]

40. González-Uribe, J.; Xu, M. Corporate Innovation Cycles and CEO Contracts; Working paper; London School of Economics: London, UK, 2015.

41. Balsmeier, B.; Fleming, L.; Manso, G. Independent boards and innovation. J. Financ. Econ. 2017, 123, 536-557. [CrossRef]

42. Stiglitz, J.E. Intellectual Property Rights, the Pool of Knowledge, and Innovation; National Bureau of Economic Research: Cambridge, MA, USA, 2014.

43. Fang, L.H.; Lerner, J.; Wu, C. Intellectual property rights protection, ownership, and innovation: Evidence from China. Rev. Finan. Stud. 2017, 30, 2446-2477. [CrossRef]

44. Chen, T. Institutions, board structure, and corporate performance: Evidence from Chinese firms. J. Corp. Financ. 2015, 32, 217-237. [CrossRef]

45. Jiao, H.; Koo, C.K.; Cui, Y. Legal environment, government effectiveness and firms' innovation in China: Examining the moderating influence of government ownership. Technol. Forecast. Soc. Chang. 2015, 96, 15-24. [CrossRef]

46. Cummings, T.; Knott, A.M. Outside CEOs and innovation. Strateg. Manag. J. 2018, 39, 2095-2119. [CrossRef]

47. Carney, M.; Zhao, J.; Zhu, L. Lean innovation: Family firm succession and patenting strategy in a dynamic institutional landscape. J. Fam. Bus. Strateg. 2018. [CrossRef]

48. Keum, D.D.; See, K.E. The Influence of Hierarchy on Idea Generation and Selection in the Innovation Process. Organ. Sci. 2017, 28, 653-669. [CrossRef]

49. Cucculelli, M. Firm age and the probability of product innovation. Do CEO tenure and product tenure matter? J. Evol. Econ. 2018, 28, 153-179. [CrossRef]

50. Allen, M.; Lewis-Western, M.F.; Valentine, K. The Innovation Consequences of Financial Regulation for Young Life-Cycle Firms; Social Science Research Network: New York, NY, USA, 2018.

51. Hayes, R.M.; Lemmon, M.; Qiu, M. Stock options and managerial incentives for risk taking: Evidence from FAS 123R. J. Financ. Econ. 2012, 105, 174-190. [CrossRef]

52. Tan, Y.; Tian, X.; Zhang, X.; Zhao, H. The Real Effects of Privatization: Evidence from China's Split Share Structure Reform; Social Science Research Network: New York, NY, USA, 2015.

53. Balsmeier, B.; Buchwald, A. Who promotes more innovations? Inside versus outside hired CEOs. Ind. Corp. Chang. 2015, 24, 1013-1045. [CrossRef]

54. Ocasio, W. Political dynamics and the circulation of power: CEO succession in US industrial corporations, 1960-1990. Adm. Sci. Q. 1994, 39, 285-312. [CrossRef]

55. Sunder, J.; Sunder, S.V.; Zhang, J. Pilot CEOs and corporate innovation. J. Financ. Econ. 2017, 123, $209-224$. [CrossRef] 
56. Chen, C.X.; Lu, H.; Sougiannis, T. The Agency Problem, Corporate Governance, and the Asymmetrical Behavior of Selling, General, and Administrative Costs. Contemp. Account. Res. 2012, 29, 252-282. [CrossRef]

57. Classen, N.; Carree, M.; van Gils, A.; Peters, B. Innovation in family and non-family SMEs: An exploratory analysis. Small Bus. Econ. 2014, 42, 595-609. [CrossRef]

58. Julius, D.J. Managing with Power: Politics and Influence in Organizations; Harvard Business Review Press: Cambridge, MA, USA, 1993.

59. Shen, W.; Cannella, A.A., Jr. Power dynamics within top management and their impacts on CEO dismissal followed by inside succession. Acad. Manag. J. 2002, 45, 1195-1206.

60. Zhang, Y.; Qu, H. The impact of ceo succession with gender change on firm performance and successor early departure: Evidence from China's publicly listed companies in 1997-2010. Acad. Manag. J. 2016, 59, 1845-1868. [CrossRef]

61. Xu, N.; Chen, Q.; Xu, Y.; Chan, K.C. Political uncertainty and cash holdings: Evidence from China. J. Corp. Financ. 2016, 40, 276-295. [CrossRef]

(C) 2019 by the authors. Licensee MDPI, Basel, Switzerland. This article is an open access article distributed under the terms and conditions of the Creative Commons Attribution (CC BY) license (http://creativecommons.org/licenses/by/4.0/). 